\title{
Species diversity indices in poultry farms' insect communities
}

\author{
P. Nykytiuk, V. Moroz, O. Komorna, Yu. Nykytiuk, A. Raschenko \\ Polissya National University, Boulevard Stary, 7, Zhytomyr, 10008, Ukraine
}

Corresponding author E-mail: pavlonykytiuk@gmail.com

Received: 01.11.2020. Accepted: 30.12.2020

\begin{abstract}
Chicken farms need to improve existing and introduce new technologies for the construction of appropriate wastewater treatment plants and processing of solid manure, which will ensure proper treatment of waste before it enters the environment. The results of determining the ecological indices of the sanitary protection zone of poultry farms indicate their negative impact on the biological diversity and richness of insect groups. In particular, the value of the Margalef species richness index is $25 \%$ less in the special protected zones in farms, compared to the control area, and the value of Shannon's species diversity by $12 \%$. Further reduction of species diversity may lead to rapid degradation of ecosystems adjacent to the area of poultry farms. The assessment of taxonomic diversity, complexity of insect groups and their competitive structure in the area of poultry production proved the inverse relationship between the percentage of eudominants and sub-precedents, as well as the predominance of the percentage of precedents over the percentage of dominant.
\end{abstract}

Keywords: Technology of environmental protection; Animal complexes; Bioindication; Protection of atmospheric air; Entomological communities; Indices of species diversity

\section{Introduction}

In modern conditions, poultry farming in Ukraine and the world is one of the main producers of important protein products, which are characterized by biological value for the human body and affordability for most consumers. The poultry industry opens the fastest and most effective way to increase the resources of environmentally friendly whole food protein, so it should enjoy national economic priority in the process of accelerated development of meat industries in conditions of insufficient supply of meat and meat products. Increasing the production of eggs and poultry meat leads to an intensification of production, on the one hand, and on the other hand to an increase in the number of livestock, which in turn leads to the accumulation of production waste.

Poultry farming is one of the developed branches of agriculture, which is characterized by both intensive development of relatively small private poultry farms and the development of high-capacity poultry keeping and fattening enterprises. The use of modern technologies reduces the impact on the environment, but does not exclude it. The study of the negative impact of poultry complexes on the environment requires attention and further research.

The problem of reliable protection of the natural environment from pollution by bird droppings, sewage and non-food waste from poultry farms is an urgent problem for all regions of Ukraine. The negative trend in this area of animal husbandry leads to unpredictable environmental consequences, the death of fauna and flora in the areas adjacent to poultry farms, the spread of infectious and invasive diseases in humans, animals and birds. According to the World Health Organization (WHO), manure, manure and wastewater from livestock enterprises, which are the main raw materials for the production of organic fertilizers, can be a source of more than 100 pathogens of infectious and invasive diseases, and in particular zoonoses. Organic waste itself can serve as a favorable environment for the development and survival of pathogenic microflora, contain increased amounts of heavy metals, pesticides, drugs, radioactive substances and other toxicants.

Today, the main characteristic of intensive animal husbandry is the keeping of a large number of animals in a small area. To get the maximum amount of products at minimum cost, some owners save space, electricity, make the process cheaper, not taking into account the natural needs of animals, and most importantly - the environmental situation, which leads to irreversible changes in the biosphere. Recently, there is a need to find alternative methods for determining the level of environmental hazard of anthropogenically loaded areas. Such areas include areas of livestock, in particular powerful poultry complexes, bordering on natural biogeocenoses. It is important to conduct an environmental assessment in order to predict and prevent the undesirable consequences of poultry farming. Among the wide arsenal of analytical, chemical, microbiological methods, the problem of biological indication, i.e., assessment of the state of the environment by the reaction of living organisms, has become relevant. Insect biodiversity indicators and plant-based bioindication could serve as additional criteria for the effectiveness of the study of the impact of poultry production on the environment.

The relevance of the study of biodiversity with the help of insects is due to their large number and importance in biogeocenoses, sensitivity to changes in biocoenotic regimes. Particularly significant air pollution, where poultry farms operate, is due to emissions of exhaust air from production facilities: poultry houses, slaughterhouses and incubators, sanitary and veterinary points. Moreover, the largest volumes of air with a high content of harmful substances come from the premises where the bird is kept. The lack of waste-free production technologies leads to the withdrawal of arable land for storage and processing of poultry manure and poultry litter. The study of the negative impact of poultry farms on the air environment is an important problem today, which requires a comprehensive environmental approach to its solution. 


\section{Materials and Methods}

The research was conducted in the sanitary protection zones in poultry farms of the Forest-Steppe zone of Ukraine during 20172019. The representatives of Coleoptera, Hemiptera, Lepidoptera, Diptera, Hymenoptera, Orthoptera, and Homoptera were analyzed. The species richness was determined by Margalef index, the species diversity index was determined by Shannon index and Simson index, the dominance index was determined by Simpson, the evenness was determined by Pielou index.

The taxonomic diversity was determined by the formula:

$$
H t=\sum_{1}^{N} P i \ln P i
$$

Complexity of the groups by the formula:

$$
C=\left(H t \frac{1}{N} \sum_{1}^{N} H\right) n,
$$

Where, $\mathrm{H}_{\mathrm{i}}$ - species abundance of taxa of the i-th level.

\section{Results and Discussion}

For 2017 data we calculated correlation between the index of species richness and species diversity $(R=0.99$ and $R=0.88$; $p<0.05)$ in the sanitary protection zone (SPA) of the poultry farm and in the control area. In addition, there was a high inverse significant correlation $(R=-0.83$ and $R=-0.69 ; p<0.05)$ between the indices of species richness of insects and the dominance of insects in both areas, and a significantly low and moderate positive correlation $(R=0.14$ and $R=0.66 ; p<0.05)$ between the indices of species richness and their evenness in the poultry farm SPA and in the control area, respectively. The species diversity index and dominance index had high negative correlation $(R=-0.90$ and $R=0.94 ; p<0.05)$, both in the poultry farm SPA and in the control area. There was low and moderate positive correlation between the index of species diversity and index of their evenness $(R=0.24$ and $R=0.55$; $\mathrm{p}<0.05)$ in the SPZ poultry farm and the control area, respectively. A significant moderate positive correlation $(R=-0.57$ and $R=-$ $0.43 ; p<0.05$ ) was found between the index of dominance and the index of evenness in both study areas (Table 1$)$.

\begin{tabular}{|c|c|c|c|c|}
\hline & $\begin{array}{c}\text { Indicator of insect } \\
\text { diversity }\end{array}$ & $\begin{array}{l}\text { Margalef species } \\
\text { richness index }\end{array}$ & $\begin{array}{c}\text { Shannon Species } \\
\text { Diversity Index }\end{array}$ & $\begin{array}{c}\text { Simpson's } \\
\text { dominance index }\end{array}$ \\
\hline \multirow{5}{*}{$\begin{array}{l}\text { E } \\
\frac{1}{0} \\
\frac{2}{2} \\
\frac{2}{3} \\
0\end{array}$} & Shannon Species & 0.99 & & \\
\hline & Diversity Index & & & \\
\hline & $\begin{array}{l}\text { Simpson dominance } \\
\text { index }\end{array}$ & 0.83 & -0.90 & \\
\hline & Pielou index & 0.14 & 0.24 & -0.57 \\
\hline & Shannon Species & 0.88 & & \\
\hline \multirow{3}{*}{$\begin{array}{l}\overline{0} \\
\text { 논 } \\
\text { 은 }\end{array}$} & Diversity Index & & & \\
\hline & $\begin{array}{l}\text { Simpson dominance } \\
\text { index }\end{array}$ & -0.69 & -0.94 & \\
\hline & Pielou index & 0.66 & 0.55 & -0.43 \\
\hline
\end{tabular}

Table 1. Correlation of species structure indicators (2017).

Here and then $p<0.05$.

In 2018, the correlation analysis (Table 2) showed that the index of species richness had moderate and high positive correlation $(R=0.48$ and $R=0.85, p<0.05)$ with the index of species diversity in the SPA of the poultry farm and control area, respectively. There were low and moderate negative correlation $(R=-0.40$ and $R=-0.77 ; p<0.05)$ between the indices of species richness and species dominance; there was high positive correlation $(R=0.79$ and $R=0.80 ; p<0.05)$ between the indices of species richness and species evenness in the SPA of the poultry farm and control, respectively.

\begin{tabular}{|c|c|c|c|c|}
\hline & $\begin{array}{c}\text { Indicator of insect } \\
\text { diversity }\end{array}$ & $\begin{array}{l}\text { Margalef species } \\
\text { richness index }\end{array}$ & $\begin{array}{l}\text { Shannon Species } \\
\text { Diversity Index }\end{array}$ & $\begin{array}{c}\text { Simpson dominance } \\
\text { index }\end{array}$ \\
\hline \multirow{5}{*}{ 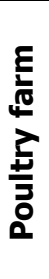 } & Shannon Species & 0.48 & & \\
\hline & Diversity Index & & & \\
\hline & $\begin{array}{l}\text { Simpson dominance } \\
\text { index }\end{array}$ & -0.40 & -0.65 & \\
\hline & Pielou index & 0.79 & 0.40 & -0.70 \\
\hline & $\begin{array}{l}\text { Shannon Species } \\
\text { Diversity Index }\end{array}$ & 0.85 & & \\
\hline \multirow{2}{*}{$\begin{array}{l}\overline{0} \\
\text { 홍 } \\
\text { 인 }\end{array}$} & $\begin{array}{l}\text { Simpson dominance } \\
\text { index }\end{array}$ & -0.77 & -0.91 & \\
\hline & Pielou index & 0.80 & 0.58 & -0.67 \\
\hline
\end{tabular}

Table 2. Correlation of species structure indicators (2018).

The moderate negative and high negative correlation $(R=-0.65$ and $R=-0.91 ; p<0.05)$ was calculated between the indices of species diversity and species dominance; also there were low and moderate positive correlation $(R=0.40$ and $R=0.58 ; p<0.05)$ between the indices of species diversity and species evenness. There was high negative correlation between the index of species dominance and 
evenness $(R=0-, 70$ and $R=-0.67 ; p<0.05)$. For the data from 2019, we calculated, the index of species richness had high positive correlation $(R=0.87$ and $R=0.98, p<0.05)$ with the index of species diversity in the SPA of the poultry farm and in the control area. There were moderate and high negative correlation $(R=-0.36$ and $R=-0.95 ; p<0.05)$ between the indices of species richness and the dominance in both areas. There were low negative correlation $(R=-0.02, p<0.05)$ and moderate positive correlation $(R=0.65$; $p<0.05)$ between the indices of species richness and their evenness in the SPZ of poultry farms and in the control area, respectively (Table 3).

Table 3. Correlation of species structure indicators (2019).

\begin{tabular}{|c|c|c|c|c|}
\hline & $\begin{array}{c}\text { Indicator of insect } \\
\text { diversity }\end{array}$ & $\begin{array}{l}\text { Margalef species } \\
\text { richness index }\end{array}$ & $\begin{array}{c}\text { Shannon Species } \\
\text { Diversity Index }\end{array}$ & $\begin{array}{l}\text { Simpson dominance } \\
\text { index }\end{array}$ \\
\hline \multirow{6}{*}{$\begin{array}{l}\frac{2}{ \pm} \\
\frac{7}{3} \\
\stackrel{0}{0}\end{array}$} & Shannon Species & 0.87 & & \\
\hline & Diversity Index & & & \\
\hline & $\begin{array}{l}\text { Simpson dominance } \\
\text { index }\end{array}$ & -0.36 & 0.70 & \\
\hline & Pielou index & -0.02 & 0.04 & 0.43 \\
\hline & Shannon Species & 0.98 & & \\
\hline & Diversity Index & & & \\
\hline \multirow{2}{*}{$\begin{array}{l}\overline{0} \\
\text { 논 } \\
\text { 웅 }\end{array}$} & $\begin{array}{l}\text { Simpson dominance } \\
\text { index }\end{array}$ & -0.95 & -0.97 & \\
\hline & Pielou index & 0.65 & 0.57 & -0.62 \\
\hline
\end{tabular}

Thus, the results of the assessment of interdependencies between species structure indicators on the example of insect groups of poultry farm SPA areas and control showed that three of the four assessed indices, namely Maragalef species richness, Shannon diversity and Pielou evenness, had a high correlation, while the Simpson dominance index had the negative correlation with the other three indices. This testified that the species dominance can be considered as a negative parameter in the analysis of the species structure. In addition, we concluded that the species richness, species diversity and species evenness along with each other informationally reflect the pattern of the species structure. The average data for three years shows that the pairwise interdependence between the studied indicators of the species structure of insect groups was much higher in the control compared to the areas of poultry farms. This indicates a weakening of the interdependence of these indices caused by the human load

\section{References}

Nahm, K.H. (2005). Factors influencing nitrogen mineralization during poultry litter composting and calculations for available nitrogen. World's poultry science journal, 61, 238-255.

Pelletier, N. (20080. Environmental performance in the US broiler poultry sector: Life cycle energy use and greenhouse gas, ozone depleting, acidifying and eutrophying emissions. Agricultural Systems, 98, 67-73.

Pielou, E.C. (1975). Ecological diversity. New York: Wiley.

Shannon, C.E. (1949). The mathematical theory of communication. Urbana: Univ. Illinois press.

Shennon, K. (1963). Rabota po teoryy ynformacyy y kibernetyky. Moscow. Izdatelstvo inostrannooy literatury, Szogi, A.A. (2009). Prospects for phosphorus recovery from poultry. Bioresource Technology, 22, 5461- 5465.

\section{Citation:}

Nykytiuk, P. Moroz, V. Komorna, O., Nykytiuk, Yu., Raschenko, A. (2020). Species diversity indices in poultry farms' insect communities.

Ukrainian Journal of Ecology, 10(6), 66-68. 